\title{
Ending Intimate Partner Homicide: A Call for Reform of Kansas Protective Order Statutes
}

Abigail Hall $^{*}$

\section{INTRODUCTION}

Debra was murdered in her Overland Park driveway on January 5, 2012. ${ }^{1}$ Her husband fired multiple bullets into her body after ambushing her outside of her home. ${ }^{2}$ Debra had a protection order against her husband, entered in November 2011. ${ }^{3}$

Passersby found Shaunda's dead body under the playground equipment of a Kansas City park on June 14, 2014. ${ }^{4}$ Video of the park shows Shaunda fleeing from a man who caught up with her, grabbed her, and led her to the playground. ${ }^{5}$ The man is later shown leaving the park alone. ${ }^{6}$ A firearm and shell casings were recovered from the crime scene. ${ }^{7}$ Shaunda had a temporary protection order against the man. ${ }^{8}$ Her murderer, just days before, had smashed her face with a spiked bat and slashed all of her tires. ${ }^{9}$

\footnotetext{
* J.D. Candidate 2016, University of Kansas School of Law. Bachelor of Social Work, 2008, University of Kansas. I would like to thank Professor McAllister, Professor Yung, Davina De La Torre and the Kansas Law Review Editors and Staff Members for their extensive help in creating, editing, and polishing this comment. It would not be where it is without these wonderful teachers, colleagues, and peers. I would also like to thank my husband, Adam, and my mother and siblings for their unwavering support and encouragement. Finally, I would like to acknowledge the undeniable bravery and heroism of the survivors of intimate partner violence. Their unmatchable and unlimited strength inspires me every day.

1. Tony Rizzo, Devastated by Loss of Debra Beaver, Friends Raise Domestic Violence Awareness, The Kansas City Star (Aug. 24, 2014, 8:25 PM), www.kansascity.com/news/local/ article1288942.html.

2. Id.

3. $I d$.

4. KCPD: Woman's Body Found in Playground at Apartment Complex in Kansas City, Mo., 41 KSHB KANSAS CITY (June 4, 2014, 11:49 AM), http://www.kshb.com/news/crime/kcpd-homic ide-investigation-underway-after-womans-body-is-found-in-kansas-city-playground.

5. Id.

6. Id

7. Id.

8. Id.

9. Id.
} 
Bobbi got a protection order against her husband in January $2006 .{ }^{10}$ Two weeks later, he showed up at her home in Clay County, Missouri, fired a rifle into the air, and chased after Bobbi. ${ }^{11}$ When he caught up to Bobbi, he shot her to death in her neighbor's front yard. ${ }^{12}$

Rose Mary has lived with a bullet in her head since $1997 .{ }^{13}$ At a protection order hearing, she informed the court that her husband "threatened to kill her every time she tried to leave him." 14 The judge entered the order. ${ }^{15}$ Unfortunately, Rose Mary's husband attempted to make good on his threat and fired a bullet into her temporal lobe weeks later. $^{16}$

All of the aforementioned women were victims of intimate partner violence (IPV). Their stories might have been different had the court required the men subject to protection orders to surrender their guns or prohibited them from purchasing one. Unfortunately, many states do not prescribe such a measure. ${ }^{17}$ Kansas is among them. ${ }^{18}$

IPV is a global epidemic, one that often results in homicide. ${ }^{19}$ While victims are murdered in a multitude of ways, the weapon of choice in the United States appears to be the firearm. ${ }^{20}$ Studies reveal that "[o]ver the past 25 years in the U.S., more intimate partner homicides have been committed with guns than with all other weapons combined." 21 In fact, much of the gun violence in the United States is a product of IPV. ${ }^{22}$ In 2011, intimate partners or family members were responsible for the

10. Murdered Women in Kansas, KANSAS STATE UnIV., http://www.k-state.edu/care/"old/ materials/Murdered\%20Women\%20in\%20Kansas.pdf (last visited May 21, 2015).

11. $I d$.

12. $I d$.

13. Amy Karan \& Helen Stampalia, Domestic Violence and Firearms: A Deadly Combination, 79 FLA. B.J. 79, 79 (2005).

14. Id.

15. $I d$.

16. $I d$.

17. See Guns and Violence Against Women: America's Uniquely Lethal Domestic Violence Problem, EVERYTOWN FOR GUN SAFETY 6, 14-30 (2014), http://everytown.org/documents/2014/ 10/guns-and-violence-against-women.pdf [hereinafter EVERYTOWN] (noting that only twenty-three states and the District of Columbia prohibit people subject to domestic violence protective orders from possessing guns, excluding Kansas).

18. Id. at 19 .

19. News Release, Violence Against Women: A Global Health Problem of Epidemic Proportions, WORLD HEALTH ORG. (June 20, 2013), http://www.who.int/mediacentre/news/releases/ 2013/violence_against_women_20130620/en/ (explaining that 38\% of women murdered worldwide are killed by an intimate partner).

20. EVERYTOWN, supra note 17.

21. Id. at 5 .

22. Id. at 2 (explaining that an "astonishing" share of gun violence is driven by domestic violence). 
homicides of at least fifty-three percent of women murdered in the United States. ${ }^{23}$

Congress has attempted to attack the problem created when IPV and guns collide, but its efforts are routinely thwarted at the state level. ${ }^{24}$ Two pieces of federal legislation aim to force firearms out of the hands of abusers, but leave the implementation of firearm removal to the individual states. ${ }^{25}$ While the federal government has the ability to prosecute when these amendments are violated, ${ }^{26}$ this does little to prevent abusers from accessing the guns in the first place. To remove the murder weapons from known abusers, the states must focus on their own civil protection order process. This is of increasing importance today because of the state trend to nullify federal gun laws. ${ }^{27}$ While the constitutionality of these laws has been called into question, ${ }^{28}$ the trend still causes concern. If these state laws are given effect, any protections awarded by federal firearm restrictions will evaporate. ${ }^{29}$

This Comment focuses on Kansas, calling for reform of the state's protective order statute. The reform should bring the following changes: (1) mandatory confiscation of all firearms and prohibition of firearm purchase while an abuser is subject to a temporary or permanent protective order because of actual, attempted, or threatened physical abuse; (2) judicial opportunity to mandate firearm confiscation and prohibition of purchase upon entrance of a temporary or permanent protection order because of non-physical forms of abuse; (3) expansion of the definition of abuse and mandatory protection order entrance upon a showing of such abuse; and (4) a process for expedited appellate review of judicial denial of an order. Part II of this Comment explains IPV and its dynamics and provides a background on the current state of the law. Part III proposes reform and discusses the most likely counter

\footnotetext{
23. Id. at 5 .

24. Emily J. Sack, Confronting the Issue of Gun Seizure in Domestic Violence Cases, 6 J. CTR. FOR FAM., CHILD. \& THE CTS. 3, 3 (2005) (explaining that many state laws have significant gaps and inconsistencies with federal law due to the confusion among enforcement agencies and the courts' confusion about their proper role in enforcing the laws).

25. Id. at 7-8; see also 18 U.S.C. $\S \S 922(\mathrm{~g})(8)-(9)(2012)$.

26. Sack, supra note 24 , at 5 .

27. Lois Beckett, Nullification: How States Are Making It a Felony to Enforce Federal Gun Laws, ProPublicA (May 2, 2013, 2:01 PM), http://www.propublica.org/article/nullification-howstates-are-making-it-a-felony-to-enforce-federal-gun-laws (describing the wave of nullification laws throughout the United States).

28. Id. (explaining that U.S. Attorney General Eric Holder wrote a letter to Kansas Governor Sam Brownback asserting that Kansas's newly-enacted gun law is unconstitutional).

29. Keely N. Kight, Back to the Future: The Revival of the Theory of Nullification, 65 MERCER L. REV. 521, 552-53 (2014).
} 
argument - that such reform is a Second Amendment violation. While this reform proposal focuses on Kansas alone, many states could reevaluate their protective order processes to fight IPV and save victims' lives. The model this Comment proposes can serve as a model for all states in their efforts to end such abuse.

\section{BACKGROUND}

\section{A. What is Intimate Partner Violence?}

Intimate partner violence (IPV) is largely misunderstood. Defined as "physical, sexual, or psychological harm by a current or former partner or spouse," ${ }^{30}$ experts reveal that IPV is far-reaching, dynamic, and has nothing to do with common relationship incompatibilities. ${ }^{31}$ IPV is not about anger, lost tempers, or private arguments. ${ }^{32}$ IPV is about power and control. ${ }^{33}$ Research shows that the violence occurs because "one person feels they are entitled to control another." 34 IPV is not the result of something that the victim did, or failed to do, but is instead the result of some "external event or the internal state" of the abuser. ${ }^{35}$

IPV comes in many forms, including verbal, physical, psychological, sexual, and economic abuse. ${ }^{36}$ In her book exploring the nature of IPV, Lenore Walker explains that the abuse occurs in a three-stage cycle. ${ }^{37}$ This cycle begins with a "tension-building phase," when there are often verbal assaults or minor incidents of abuse that make the victim feel as if she $^{38}$ is walking on eggshells. ${ }^{39}$ This stage is followed by the "acute

30. Intimate Partner Violence: Definitions, CTRS. FOR DiSEASE CONTROL \& PREVENTION, http://www.cdc.gov/violenceprevention/intimatepartnerviolence/definitions.html (last visited May 21, 2015).

31. Why Do Abusers Batter?, The AlA. COAL. AgAinst DOMESTIC Violence, http://www.aca dv.org/abusers.html (last visited May 21, 2015) [hereinafter ACADV].

32. $I d$.

33. Mary P. Brewster, Domestic Violence Theories, Research, and Practice Implications, in Handbook of Domestic Violence Intervention Strategies: Policies, Programs, \& Legal REMEDIES 23, 30 (Albert R. Roberts, ed. 2002).

34. What is Domestic Violence, NAT'L COAL. AgAinst Domestic Violence, http://www.nca dv.org/need-support/what-is-domestic-violence (last visited May 21, 2015) [hereinafter NCADV].

35. Sharon L. Gold, Note, Why Are Victims of Domestic Violence Still Dying at the Hands of Their Abusers? Filling the Gap in State Domestic Violence Gun Laws, 91 KY. L.J. 935, 938 (2003).

36. NCADV, supra note 34 .

37. LeNORE E. WALKer, THE BATTERED WOMAN 56-59 (1979).

38. Because eighty-five percent of IPV victims are women at the hands of men, and for ease of understanding, this Comment will use female pronouns to describe victims and male pronouns to describe abusers. See infra note 45 and accompanying text.

39. WALKER, supra note 37 , at 56-59. 
battering incident," which is usually a severe form of violence that can result in injury or death. ${ }^{40}$ Finally, the victim experiences "the honeymoon stage," when the abuser showers her with gifts, compliments, and apologies, promising to never commit another act of abuse or violence. ${ }^{41}$ This cycle is often integral to the abuser's efforts to convince the victim to stay. ${ }^{42}$ The first phase begins again after the "honeymoon stage," and the cycle continues. ${ }^{43}$

IPV is not limited to one race, socioeconomic class, or by sexual orientation, but instead spans all classes of people. ${ }^{44}$ However, IPV disproportionately affects women. ${ }^{45}$ According to statistics compiled by the Centers for Disease Control and Prevention (CDC), the violence to which these women fall victim is epidemic $;^{46}$ one in three women will report surviving some type of IPV in her lifetime. ${ }^{47}$ The CDC estimates that $6,982,000$ U.S. women experience domestic violence in a twelvemonth period. ${ }^{48}$

\section{B. How does a Victim Combat Intimate Partner Violence?}

While it is becoming more common to focus on eliminating the abuse to stop IPV, the general feeling remains that if a victim wants the abuse to end she should leave the relationship. ${ }^{49}$ Because of this societal attitude, it is important to explain the difficulties involved with leaving an abusive relationship to demonstrate that the answer to IPV does not lie with the victim.

When a woman is being abused by an intimate partner, she faces a series of difficult decisions. The first is whether she should attempt to do anything about the abuse. There are many reasons why the victim may

\footnotetext{
40. Id. at $59-65$.

41. Id. at $65-70$.

42. See Gold, supra note 35, at 939 (explaining the factors that perpetuate the cycle).

43. Id.

44. Id. at 937.

45. See Jennifer L. Vainik, Kiss, Kiss, Bang, Bang: How Current Approaches to Guns \& Domestic Violence Fail to Save Women's Lives, 91 MinN. L. REV. 1113, 1116 (2007) (reporting that eighty-five percent of IPV victims are women whose abusers are men).

46. See Michele C. Black et al., The National Intimate Partner and Sexual Violence Survey, NAT'L CTR. FOR INJURY PREVENTION \& CONTROL 1 (2011), http://www.cdc.gov/violence prevention/pdf/nisvs_report2010-a.pdf ("Sexual violence, stalking, and intimate partner violence are major public health problems in the United States.").

47. Id. at 2 .

48. Id. at 38 .

49. Dawn Bradley Berry, The Domestic Violence SourCeBook 116-17 (1995).
} 
elect to do nothing. ${ }^{50}$ First, the level of psychological manipulation in IPV is high, and often the victim inherently believes that the abuse is her fault. ${ }^{51}$ She takes full responsibility for the abuse and feels that if she can just be a better partner, the violence will stop. ${ }^{52}$ Second, the victim is often deeply in love with her abuser. ${ }^{53}$ Because the abuse generally starts later in the relationship, intricate feelings of love, loyalty, and affection will already exist when the violence begins. ${ }^{54}$ It may be difficult for a person to jeopardize a relationship like this, especially if one truly believes the "difficulties" arise from personal fault and failure. ${ }^{55}$ Third, children are often involved. ${ }^{56}$ This complicates a decision to take action, either because a victim is afraid that the children will lose access to a father figure or that she herself will lose access to the children. ${ }^{57}$ Finally, there is the very real risk of victim blaming. ${ }^{58}$ As history has shown, female IPV survivors are often blamed for the abuse, or ostracized once they reach out. ${ }^{59}$ This is evident in the first question that our society often asks about an IPV situation: "Why doesn't she leave?"60 Attitudes are beginning to change, but it is slow moving, and a victim is right to assume that she may be publicly blamed, humiliated, or cut off from any support circle she has managed to maintain. ${ }^{61}$

Should the victim decide she will fight her instincts to try to be a better partner, protect her children, or avoid public shaming, she then must decide if it is more dangerous to do something about the abuse or to try and live through it. Because perpetrators of IPV try to keep control over their victims, any sense that they are losing that control will likely provoke more violence, or even homicide. ${ }^{62}$ When a victim decides to risk this, she may first approach the idea of batterer's intervention or counseling. ${ }^{63}$ Because this does not often work, the victim who braves 
the road of pushing even further usually must come to the decision to leave if she is to make the abuse stop. ${ }^{64}$

Leaving an abusive relationship comes with seemingly insurmountable challenges. Often, the abuser has cut the victim off from access to money by confiscating her paychecks or making sure that she does not have a job. ${ }^{65}$ Thus, she may be financially unable to support herself or her children if she leaves. ${ }^{66}$ The abuser usually keeps his victim isolated, destroying relationships she had with family or friends. ${ }^{67}$ Then, when his victim wants to leave, she often has no one to whom she can turn. ${ }^{68}$ Most significantly, the victim runs the risk of being killed if she does try to flee. ${ }^{69}$ Because of the abuser's isolation tactics and propensity for violence, the victim will normally need help to survive an escape.

First instincts suggest that a victim should call the police for help. If the abuser is arrested for his acts of violence, this will accomplish two things: the victim will have a clear path to escape as long as the perpetrator is in custody, and the abuser will theoretically have to answer for his actions. However, this is only helpful if there has been an incident of physical violence or a threat of physical violence, ${ }^{70}$ and even then, arrest does not always result in conviction. ${ }^{71}$ There are some IPV relationships that never see physical or sexual violence. ${ }^{72}$ In these instances, the victim cannot turn to the criminal justice system.

A civil protection order can help a victim secure her safety when trying to leave a violent relationship. These orders are entered by a state court and can order a variety of things, from prohibiting abuse to requiring the surrender of any firearms to mandating that the abuser have no contact with the victim. ${ }^{73}$ The orders are governed by state statute. ${ }^{74}$

\footnotetext{
64. Id.

65. BERRY, supra note 49 , at 117.

66. ACADV, supra note 31 .

67. BERRY, supra note 49, at 117.

68. ACADV, supra note 31.

69. EVERYTOWN, supra note 17.

70. See KAn. StAT. ANN. § 22-2401 (2007) (only permitting arrest when there is probable cause that a crime has been committed).

71. See Andrew R. Klein, Practical Implications of Current Domestic Violence Research: For Law Enforcement, Prosecutors, and Judges, NAT'L Inst. OF JustiCe (June 2009), http://www. ncjrs.gov/pdffiles $1 /$ nij/225722.pdf (reporting that the average prosecution rate after an IPV arrest is $63.8 \%$ but is as low as $4.6 \%$ in some jurisdictions).

72. NCADV, supra note 34.

73. Catherine F. Klein \& Leslye E. Orloff, Providing Legal Protection for Battered Women: An Analysis of State Statutes and Case Law, 21 HofsTRA L. ReV. 801, 910-34 (1993).

74. See Domestic Violence Civil Protection Orders (CPOs) By State, AM. BAR Assoc.
} 
When a victim wants a protection order, she files a petition with the local state court. Generally, these orders can be granted on an emergency and temporary ex parte basis. ${ }^{75}$ This means that the order is granted immediately and takes effect as soon as the abuser is served with papers. $^{76}$ How long this ex parte order lasts depends on the state law where it was obtained. ${ }^{77}$ Some states mandate a hearing within two weeks of service to determine if the ex parte order will become final. ${ }^{78}$ Other states allow longer time. ${ }^{79}$ Some states will leave the order in place indefinitely unless the abuser decides to request a hearing. ${ }^{80}$ While ultimately these orders are just a court order on a piece of paper, they have proved successful for some in combating IPV and helping victims to escape to safety. ${ }^{81}$

\section{Intimate Partner Violence and Guns}

Some victims survive IPV, and some manage to escape, often with the help of civil protection orders. ${ }^{82}$ Too frequently this is not the case, and the IPV lasts the entire life of the abuser, or it ends with the murder of the victim. ${ }^{83}$ When an abuser has access to a firearm, the likelihood that the abuse ends in murder dramatically increases. ${ }^{84}$ An abused woman is five times more likely to be murdered if her abuser owns a gun. ${ }^{85}$ Assaults on an intimate partner or family member are twelve times more likely to end in death when a firearm is involved. ${ }^{86}$

\footnotetext{
COMM'N ON DOMESTIC VIOLENCE (June 2007), http://www.americanbar.org/content/dam/ aba/migrated/domviol/docs/DVCPOChartJune07.authcheckdam.pdf (outlining each state statute governing civil protection orders).

75. Klein \& Orloff, supra note 73 , at 1037.

76. Id. at 1067 .

77. Id. at $1086-87$.

78. Id. at 1040 .

79. Id. at $1040-42$.

80. Id. at 1085 .

81. See id. at 813 (identifying the factors that contribute to the effectiveness of protection orders).

82. See id. at 974

83. See When Men Murder Women: An Analysis of 2009 Homicide Data, Violence Policy CTR. (Sept. 2011), http://www.vpc.org/studies/wmmw2011.pdf [hereinafter 2009 Homicide Data].

84. Elizabeth Richardson Vigdor \& James A. Mercy, Do Laws Restricting Access to Firearms by Domestic Violence Offenders Prevent Intimate Partner Homicide?, 30 Evaluation Rev. 313, 314 (2006).

85. Domestic Violence and Policy Firearms Summary, LAw CTR. To Prevent Gun Violence (May 11, 2014), http://smartgunlaws.org/domestic-violence-firearms-policy-summary/ [hereinafter Firearms Policy Summary].

86. Linda E. Saltzman et al., Weapon Involvement and Injury Outcomes in Family and Intimate Assaults, 267 J. AM. MED. Ass'N, 3043, 3046 (1992).
} 
In 2009 , at least 1,818 women were the victims of homicide. ${ }^{87}$ An intimate partner perpetrated at least sixty-three percent of these homicides. ${ }^{88}$ More than half of the 2009 female victims were murdered with a gun. ${ }^{89}$ Because the study that produced those results excluded exboyfriends from the killers, the number is likely even higher. ${ }^{90}$

Abusers use guns for more than murder. ${ }^{91}$ A gun is often a tool in forcing the victim to stay in the abusive relationship. ${ }^{92}$ The abuser will threaten to kill himself, his victim, or the victim's children if she tries to leave. IPV literature suggests that even the mere possession of a firearm without these explicit threats can achieve the same threatening result, causing the victim to stay in the relationship out of fear. ${ }^{93}$ Often, the violence is at its worst immediately after a victim attempts to leave the batterer, so the fear is not unrealistic. ${ }^{94}$

Guns are a problem even when a protection order is in effect. Abusers violate protection orders. ${ }^{95}$ Studies show that violations range from twenty-three percent in two years to sixty percent in one year. ${ }^{96}$ When an abuser has a firearm during that violation, results can be deadly. ${ }^{97}$ A Massachusetts study shows that abusers subject to protective orders who had access to firearms were more likely to attempt homicide or threaten partners with guns than those who had been forced to relinquish their weapons. ${ }^{98}$ Unless the protection order mandates the confiscation of firearms, the abuser could have a firearm in his

87. 2009 Homicide Data, supra note 83, at 3 (explaining in 2009 there were 1,818 females in single victim/single offender homicide).

88. Id.

89. Id. at 7 (noting the number of times guns were used in a homicides where the weapon could be identified).

90. Id.

91. Michelle N. Deutchman, Getting the Guns: Implementation and Enforcement Problems with California Senate Bill 218, 75 S. CALIF. L. REV. 185, 186 (2001) ("Although domestic violence can take many forms, abusers often use firearms to threaten, injure, or kill their victims."); see also 2009 Homicide Data, supra note 83, at 1 ("Gun use does not need to result in a fatality to involve domestic violence.").

92. See Deutchman, supra note 91 , at 186 .

93. Vigdor \& Mercy, supra note 84.

94. Gold, supra note 35 , at 940 .

95. Klein, supra note 71.

96. Id.

97. See Firearms Policy Summary, supra note 85 (summarizing statistics illustrating the high likelihood of homicide when an abuser has a firearm).

98. Id. 
possession. ${ }^{99}$ Statistics reveal numerous homicides perpetrated by abusers who were prohibited from having a firearm. ${ }^{100}$

\section{Legislative Response to IPV}

Until recently, little legislation spoke specifically to the IPV epidemic. ${ }^{101}$ If addressed at all, domestic violence had to be combated through general criminal assault statutes or regular civil restraining orders. ${ }^{102}$ Beginning in the 1970 s, lawmakers started responding to IPV at both the state and federal level. ${ }^{103}$ The statutes allowing protection orders were among the first answers ${ }^{104}$ to demands for action. ${ }^{105}$ By the 1990 s, every state offered some type of civil protection order. ${ }^{106}$ Congress followed this state response, first with federal funds to assist victims, and eventually with the inclusion of domestic violence in new crime bills in an effort to specifically criminalize IPV. ${ }^{107}$ Legislation has also addressed the issue of gun violence in abusive relationships at both the state and federal level. ${ }^{108}$

\section{The Current State of Federal Domestic Violence and Gun Law}

Current federal law aims to keep IPV victims safe by taking guns out of the hands of abusers. ${ }^{109}$ This goal is reflected in two separate provisions. ${ }^{110}$ One of these provisions, 18 U.S.C. $\S 922(\mathrm{~g})(9)$, is commonly known as the Lautenberg Amendment. ${ }^{111}$ It effectively prohibits anyone convicted of a domestic violence misdemeanor from

\footnotetext{
99. $I d$.

100. Id.

101. Kellie K. Player, Expanding Protective Order Coverage, 43 ST. MARY's L.J. 579, 584 (2012).

102. Alison J. Nathan, At the Intersection of Domestic Violence and Guns: The Public Interest Exception and the Lautenberg Amendment, 85 CORNELL L. REV. 822, 830 (2000).

103. Player, supra note 101, at 584.

104. Id. at 583-84.

105. See, e.g., Patricia Sully, Taking it Seriously: Repairing Domestic Violence Sentencing in Washington State, 34 SeAtTLE U. L. REV. 963 (2001).

106. Player, supra note 101, at 584 (citing Judith A. Smith, Battered Non-Wives and Unequal Protection-Order Coverage: A Call for Reform, 23 YALE L. \& POL'Y REV. 93, 99-100 (2005); Kit Kinports \& Karla Fischer, Orders of Protection in Domestic Violence Cases: An Empirical Assessment of the Impact of the Reform Statutes, 2 TEX. J. WOMEN \& L. 163, 165 (1993)).

107. Nathan, supra note 102 , at 830.

108. Id. at $830-31$.

109. Id. at $824-26$.

110. 18 U.S.C. $\S 922(2012)$

111. Nathan, supra note 102 , at 837 .
} 
possessing a firearm. ${ }^{112}$ The amendment received overwhelming support, passing with a vote of ninety-seven to two in the Senate. ${ }^{113}$ The support was bolstered by the fact that domestic violence convictions are commonly plea bargained down from felonies to misdemeanors, allowing abusers to escape existing felon firearm bans. ${ }^{114}$

The Lautenberg Amendment was preceded by 18 U.S.C. $\S 922(\mathrm{~g})(8)$, which prohibits persons subject to a protection order from possessing a firearm. ${ }^{115}$ Under this firearm prohibition, the firearm restriction is effective only after the abuser has had notice of a hearing and an opportunity to respond, and there has been either a finding of abuse or an order mandating that the abuser refrains from abusing, harassing or stalking the victim. ${ }^{116}$ Unlike the Lautenberg Amendment, this firearm prohibition contains an exemption for members of the police force or military. ${ }^{117}$

While this protective order statute is one of federal creation and consequence, the provisions are enforced at the state level. ${ }^{118}$ The amendment establishes a federal offense in the possession of a firearm when one is subject to a state protective order, but leaves the entrance of the protective order to the discretion of state trial courts. ${ }^{119}$ The statute is also devoid of any process or mechanism to ensure that guns are actually relinquished if and when an order is entered. ${ }^{120}$

\section{State Approaches to IPV and Guns}

State approaches to domestic violence and firearms vary greatly. ${ }^{121}$ Some states mandate seizure of firearms whenever an officer is at the scene of an IPV incident. ${ }^{122}$ Others prohibit anyone with a domestic violence conviction from keeping or buying a gun. ${ }^{123}$ A majority of the state legislation aimed at IPV comes in the form of restrictions when

\footnotetext{
112. 18 U.S.C. $\S 922$.

113. Nathan, supra note 102 , at 826 n.31.

114. Id. at 837 .

115. 18 U.S.C. $\S 922(\mathrm{~g})(8)(2012)$.

116. Id. $\S 922(\mathrm{~g})(8)(\mathrm{A})$.

117. Nathan, supra note 102 , at 836 .

118. See id. at 826.

119. Vainik, supra note 45, at 1136.

120. Id.

121. Id. at 1123 .

122. Id. at 1123-24.

123. Id.
} 
someone is subject to a protective order. ${ }^{124}$ Many states allow or require courts issuing the order to mandate the surrender or confiscation of a firearm owned by the abuser. ${ }^{125}$

Thirty-six states and Washington D.C. have legislation that either permits or requires a court to forbid firearm possession and purchase by abusers subject to a protective order. ${ }^{126}$ At least five of these states prohibit the purchase or possession upon the entrance of an ex parte protection order. ${ }^{127}$ At least three states require or authorize law enforcement to remove the weapons from an abuser. ${ }^{128}$ California even permits a search warrant if the subject will not voluntarily hand over his firearms. ${ }^{129}$ However, other states-Kansas among them-have no mention of firearm surrender or removal whatsoever. ${ }^{130}$

\section{How State and Federal Gun Laws Work Together}

The absence of any provision in the federal gun laws designating process or procedure for removing firearms puts a great amount of power and responsibility in the hands of state trial judges. ${ }^{131}$ These judges decide whether the federal statute will apply to a respondent because they decide if a protection order will be granted. ${ }^{132}$ The judges listen to the cases that the petitioners bring forward and decide, based on varying state statutes, whether there are grounds for a protection order. ${ }^{133}$ From here, what happens with an abuser's firearm generally depends on what is included in that state's statute. ${ }^{134}$

Many of the current state protective order statutes give great deference to judicial discretion in deciding whether to enter an order and whether to prohibit the abuser from possessing or purchasing a gun. ${ }^{135}$ This judicial discretion can have lethal consequences for a victim when the judge hearing her case does not understand the dynamics of IPV or

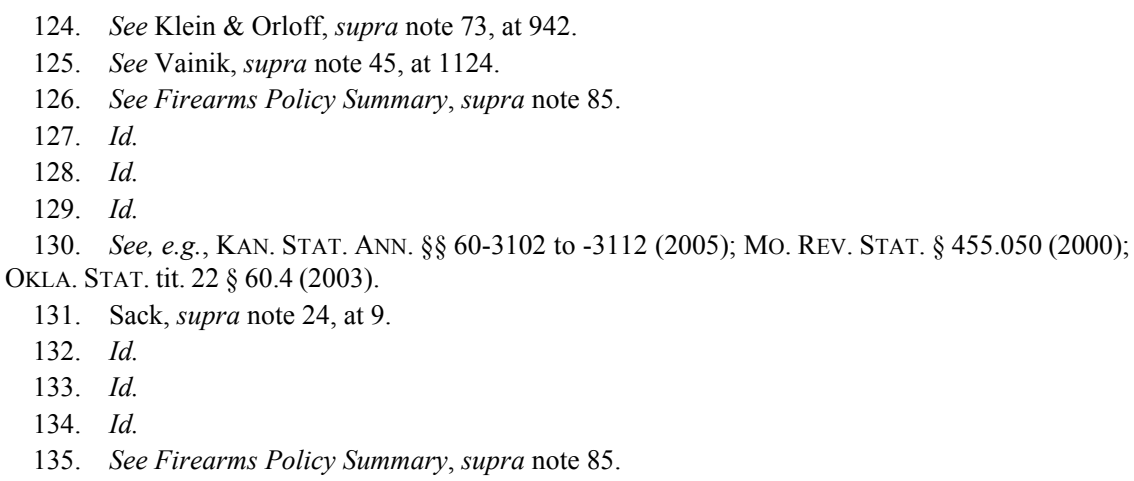


the seriousness of the situation. ${ }^{136}$ When this happens, the judge may engage in victim blaming, and put the responsibility of ending the abuse on the survivor instead of the abuser, surmising that the victim would just leave if there was really a problem. ${ }^{137}$ In this situation, the judge refuses to grant an order or prohibit firearm possession because they doubt the validity of the victim's fear or the abuser's potential for violence. This leaves the victim with no protection, a very angry abuser, and little faith in the system that she reached out to for help.

Judges may also be actively denying orders in an effort to avoid denying someone a right to a firearm, either because of personal belief or constitutional concerns. ${ }^{138}$ The latter attitude is often prevalent in avid hunting communities. ${ }^{139}$ Some commenters even believe that judges may be denying orders or firearm relinquishment demands because they would rather not be bothered. ${ }^{140}$ Confiscating firearms can be an administrative hassle and creates extra work. ${ }^{141}$ When a judge does not think that IPV is serious, it may be tempting to avoid the extra work and theoretically let the parties work it out themselves. ${ }^{142}$

\section{E. Nullification of Federal Law by the States}

There is a recent trend among the states to nullify federal gun laws. ${ }^{143}$ These state laws, referred to as Firearms Freedom Acts (FFAs), purport to void federal firearm restrictions so long as the weapons are created, sold and kept within state lines. ${ }^{144}$ The states' agendas are propelled by the idea that the federal firearms laws are unconstitutional and therefore null and void. ${ }^{145}$

\footnotetext{
136. See Deutchman, supra note 91, at 209 (discussing judicial attitudes toward firearm relinquishment provisions).

137. Id.

138. See id. (stating that many judges resist implementation of firearm relinquishment provisions on the basis of "protect[ing] the rights of gun owners" (citing Telephone Interview with Mary B. Malefyt, Senior Attorney, Full Faith and Credit Project, Pennsylvania Coalition Against Domestic Violence, D.C. Legal Office (Jan. 26, 2011))).

139. Id.

140. Id. (quoting Telephone Interview with Gail Pincus, Director, Domestic Abuse Center (Nov. $6,2000))$.

141. Id. (quoting Telephone Interview with Gail Pincus, Director, Domestic Abuse Center (Nov. $6,2000))$.

142. See id.

143. See Beckett, supra note 27.

144. Kight, supra note 29, at 522 n.11 (noting that Alaska, Arizona, Idaho, Kansas, Montana, South Dakota, Tennessee, Utah, and Wyoming have all passed FFAs).

145. Id. at 523
} 
Nullification is a recycled theory-one that first arose in 1798 to oppose the Alien and Sedition Acts. ${ }^{146}$ Southern states revived the doctrine in 1832 in opposing federal tariffs. ${ }^{147}$ While both of these attempts were unsuccessful in establishing nullification as a successful method for challenging federal law, the theory returned when abolitionists used it to oppose the Fugitive Slave Act, and again after the Civil War in an effort to refuse federal action to end segregation. ${ }^{148}$ The doctrine was then put to rest until the 1990s, when states began permitting the use of medical marijuana in defiance of federal bans against the drug. ${ }^{149}$

Today, the states have brought back the nullification theory, claiming that Congress has operated outside of the true reach of the Commerce Clause with its federal gun restrictions. ${ }^{150}$ These states assert that Congress has no power to regulate firearms of purely local commerce. ${ }^{151}$ Nine states have successfully passed FFAs fueled by this idea. ${ }^{152}$ Missouri almost joined the growing list in 2013 with a bill that would not only nullify federal gun laws within the state, but make it a crime for officers to enforce those laws. ${ }^{153}$ The governor vetoed the bill. ${ }^{154}$ While the FFAs have received a negative response from the federal courts, ${ }^{155}$ they still stand in eight out of the nine states ${ }^{156}$ and have been introduced in many others. ${ }^{157}$

\section{Nullification in Kansas}

Kansas is among the nine states that have enacted a nullification law. ${ }^{158}$ Governor Sam Brownback signed the Kansas FFA legislation in

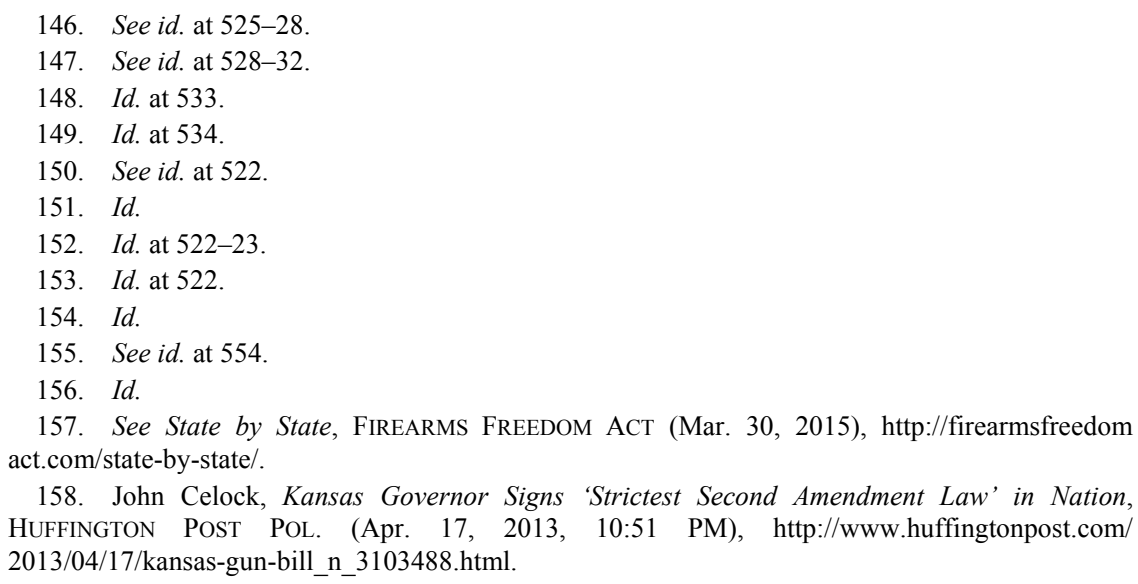


April 2013. ${ }^{159}$ This FFA, or the "Second Amendment Protection Act," declares all firearms produced and kept in Kansas exempt from federal restrictions. ${ }^{160}$ It also prohibits any agency from enforcing those federal restrictions. ${ }^{161}$ According to the Brady Center to Prevent Gun Violence, this FFA could have extensive effect, allowing "some federally prohibited people to buy and possess guns, prohibit federal background checks for gun purchases and allow the unlicensed manufacturing of firearms in Kansas, including guns designed to evade metal detectors and airport security screenings. The law could also cripple investigations of gun trafficking and illegal gun sales."162 Because the Lautenberg Amendment and 18 U.S.C. $\S 922(\mathrm{~g})(8)$ are federal law, the Kansas FFA theoretically removes protections for IPV survivors that Congress implemented.

The FFA's destruction of the federal gun control amendments appears merely theoretical in nature because the federal government has openly declared that the law is unconstitutional. ${ }^{163}$ Shortly after the FFA's enactment, Attorney General Eric Holder informed Governor Brownback that the law violated the Supremacy Clause and federal agencies would not observe its mandates. ${ }^{164}$ Federal firearms restrictions will continue to be enforced, said Holder, and Kansas will risk litigation if enforcement is impeded. ${ }^{165}$

In fact, the FFA is already facing litigation, but from a different source. ${ }^{166}$ The Brady Center to Prevent Gun Violence filed a lawsuit to strike down the law in July 2014. ${ }^{167}$ The complaint was filed in the U.S. District Court of Kansas. ${ }^{168}$ The Brady Center claims that the FFA is a violation of the Supremacy Clause and is unconstitutionally vague. ${ }^{169}$ The Center argues that the firearms regulation is well within Congress's reach under the Commerce Clause, and therefore it cannot be voided by

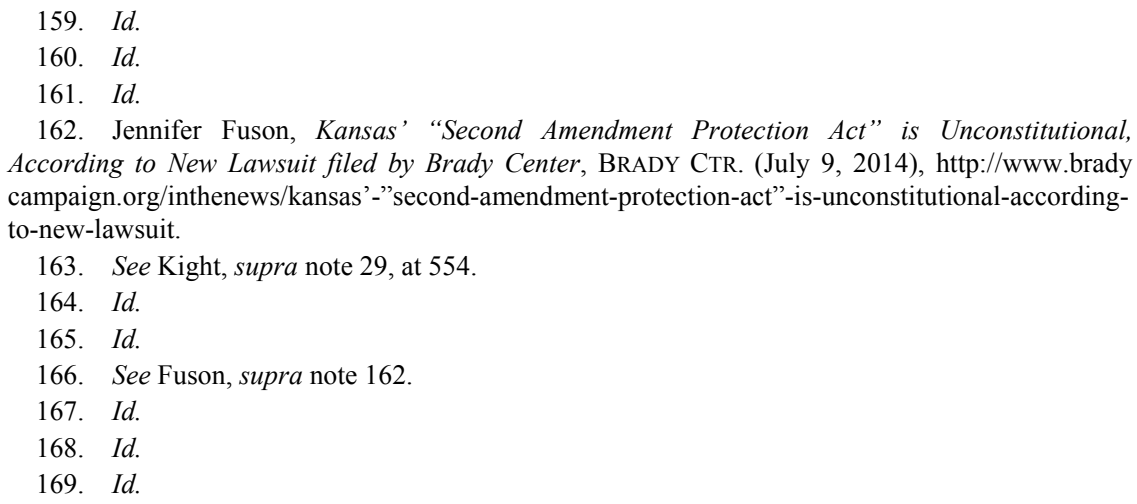


state legislation. ${ }^{170}$ The court has yet to hear any argument on the suit, but FFA advocates claim that even a successful legal challenge will not stop their efforts to eradicate gun restrictions. ${ }^{171}$ Patricia Stoneking, President of the Kansas State Rifle Association, explains that "[e]ven if Kansas' law ends up being struck down in court, 'We actually are not going to roll over and play dead and say, "Oh, no, shame on us". ... 'The fight will not be over.",'172

\section{What Nullification means for IPV}

Because it invalidates current federal firearm restrictions, the nullification trend could have an incredible impact on IPV. The FFAs will result in "fewer registration and reporting requirements, fewer prohibitions on classes of people who may own firearms, and fewer restrictions on types of firearms." ${ }^{173}$ If states elect to nullify federal gun laws, neither 18 U.S.C. § 922(g)(8) nor the Lautenberg Amendment will prevent abusers from obtaining and possessing firearms within the states that have nullified federal law. ${ }^{174}$ While the high rate of IPV homicide suggests that the federal restrictions are far from enough in the battle to keep victims safe, they have provided a noticeable impact on the reduction of abusers with guns. ${ }^{175}$ Between 1998 and 2015, over 114,000 IPV perpetrators were prevented from purchasing a firearm because of federal gun control laws. ${ }^{176}$

\section{F. Kansas Protective Order Laws}

Kansas offers two different types of civil protection orders for survivors of IPV. ${ }^{177}$ Petitioners who are or were in an intimate relationship with their abusers or lived in the same houses as their abusers may seek a protection from abuse order (PFA). ${ }^{178}$ The judge may grant the PFA if the petitioner can show one of the following three

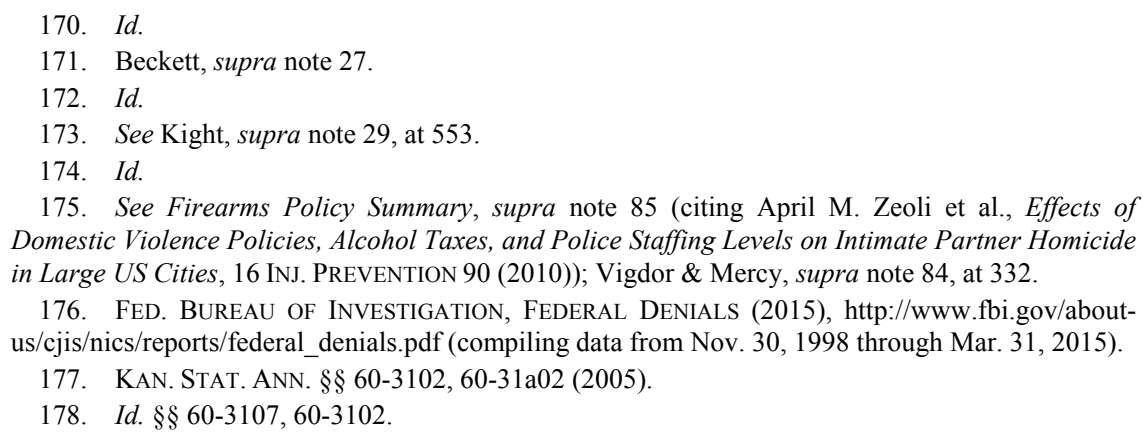


things: (1) the abuser has intentionally caused bodily injury; (2) the abuser tried to cause bodily injury; or (3) the abuser intentionally made the victim fear she would receive bodily injury. ${ }^{179}$ Kansas also offers a protection from stalking order (PFS). ${ }^{180}$ Anyone who is the victim of intentional harassment that has made the victim fear for her safety may seek a PFS without having lived with or dated the stalker. ${ }^{181}$ Because this Comment concerns IPV, which is most regularly addressed through a PFA and not a PFS, the discussion will only addresses the PFA.

The PFA can be entered on a temporary, ex parte basis, pending a hearing. ${ }^{182}$ The judge may enter the PFA ex parte if the petitioner can show good cause, defined as "immediate and present danger of abuse to the plaintiff." 183 The hearing for a PFA ex parte or regular petition must be scheduled within twenty days of the granting of the ex parte order or the entrance of the petition. ${ }^{184}$

The PFA does not prohibit possession or purchase of firearms when someone is subject to the protective order. ${ }^{185}$ It does allow for judicial discretion in ordering any other needed relief, but the statutes are absent any mention of guns. ${ }^{186}$ While the entrance of a PFA can trigger 922(g)(8), making it a federal offense for the respondent to possess a firearm, the federal provision has little effect on state level PFAs.

\section{ANALYSIS}

Separating abusers from their murder weapons is an essential action that can be accomplished with help from state legislatures. This action can begin in Kansas. Mandatory firearm removal and prohibition of firearm purchases upon entrance of an ex parte or permanent protection order due to physical violence is the first step. In addition, judges should be afforded the ability to command firearm confiscation upon entrance of a protection order for forms of non-physical abuse. With these new provisions, the protective order statute will also need to account for judges who do not enter orders because they are fearful of crossing constitutional lines or personal beliefs to gun rights. Therefore, the

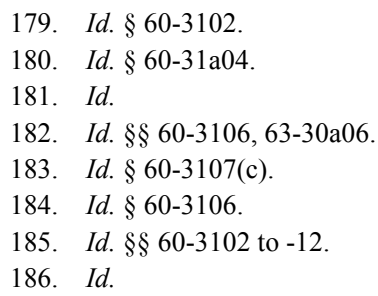


statute should mandate that orders are entered upon certain findings of fact. Finally, the statute should outline a process for quicker appellate review. These orders can be the difference between life and death. Should a judge's strong ideals about a constitutional right to guns prevent her from entering an order, the victim should have an opportunity to have the decision reviewed before it is too late.

\section{A. Proposed Kansas Protective Order Reform}

\section{Firearm Removal and Prohibition of Purchase}

There are a variety of firearm provisions among state protective order statutes, ranging from no restriction at all to orders that command police seizure of guns. ${ }^{187}$ Studies show that the statutes with more restrictive provisions are saving lives. ${ }^{188}$ After states pass these laws, intimate partner homicide decreases by eight percent. ${ }^{189}$ Because it will save the lives of its citizens, Kansas should implement more restrictive means.

The Massachusetts protective order statute provides a good example of more restrictive legislation. It mandates the following:

Upon issuance of a temporary or emergency order ... the court shall, if the plaintiff demonstrates a substantial likelihood of immediate danger of abuse, order the immediate suspension and surrender of any license to carry firearms and or firearms identification card which the defendant may hold and order the defendant to surrender all firearms, rifles, shotguns, machine guns and ammunition which he then controls, owns or possesses .... Law enforcement officials, upon the service of said orders, shall immediately take possession of all firearms, rifles, shotguns, machine guns, ammunition, any license to carry firearms and any firearms identification cards in the control, ownership, or possession of said defendant. ${ }^{190}$

The court may issue the temporary order whenever it finds the order necessary to protect the petitioner from abuse. ${ }^{191}$ If issued, the respondent must have an opportunity to be heard within ten days of the order. ${ }^{192}$ If the respondent does not appear or give reason why the order

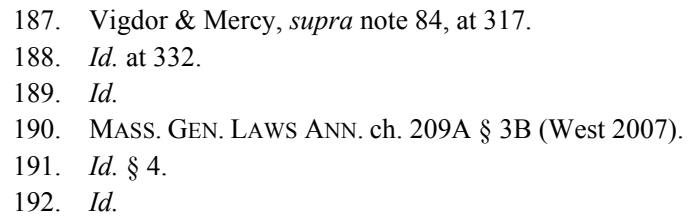


should not be continued, the judge will make the order permanent for one year. ${ }^{193}$ This will include the firearm prohibition. ${ }^{194}$

In contrast, the Kansas protective order statutes say nothing about a firearm prohibition. ${ }^{195}$ The Legislature should amend these laws to incorporate mandates like those included in the Massachusetts statute. Specifically, the PFA statute should divide firearm prohibition into two categories: mandatory prohibition in situations of physical violence and optional prohibition in situations of non-physical violence. Kansas law should command the surrender of firearms upon entrance of an emergency ex parte or permanent order when such an order is the result of actual, attempted, or threatened physical or sexual violence. In addition, the statute should allow judges to order the confiscation of firearms when the abuser is perpetrating forms of non-physical violence. In either situation, the legislation should mandate police removal when weapons are not surrendered voluntarily.

The statute should provide that the firearm prohibitions will stay in place until the PFA is lifted. Upon termination of the order, any confiscated firearms will be returned to the respondent. If firearms are confiscated upon entrance of an ex parte order and the permanent order is subsequently denied, the firearms will be returned to the respondent upon that denial. If an ex parte order is denied but a permanent order entered, surrender of firearms will be mandated upon entrance of that permanent order. The following is a possible example of the proposed legislation:

The Court shall enter a protection from abuse order upon a finding of domestic abuse.

This order shall mandate the surrender of all firearms and ammunition and prohibit the purchase of firearms and ammunition when there has been an incident of:

(a) physical or sexual abuse;

(b) attempted physical or sexual abuse; or

(c) threatened physical or sexual abuse.

The court may order the surrender of all firearms and ammunition and prohibit the purchase of firearms and ammunition when there is a presence of non-physical domestic abuse.

193. Id. 209A § 3(i).

194. Id. § 3C

195. See KAn. Stat. AnN. §§ 60-3101 to -3112 (2005). 


\section{Implementation}

Because the proposed reform will not only command surrender of firearms, but mandate police confiscation when the firearms are not surrendered, the PFA orders need to be accompanied by search warrants. The New Hampshire protective order statute provides for such relief, declaring that:

The court may subsequently issue a search warrant authorizing the peace officer to seize any deadly weapons specified in the protective order and any and all firearms and ammunition, if there is probable cause to believe such firearms and ammunition and specified deadly weapons are kept on the premises or curtilage of the defendant and if the court has reason to believe that all such firearms and ammunition and specified deadly weapons have not been relinquished by the defendant. $^{196}$

The Kansas PFA statute should include such a provision. In the case of a temporary ex parte order, the warrant should be attached directly to the ex parte order when a judge grants an emergency PFA. When law enforcement serves the respondent with the ex parte papers, the warrant will be ready to go in the event the abuser refuses to surrender weapons. If there is a permanent protection order without a prior ex parte order, the search warrant should be attached to that permanent order that is entered in the courtroom. Respondents should then have the opportunity to turn over their weapons within seventy-two hours. If weapons are not surrendered, law enforcement will secure the weapons with the prepared search warrant.

Because the weapons will be returned to the respondents when the order is lifted, law enforcement will retain the weapons until the PFA expires. Upon expiration of the order, the respondent should be afforded thirty days to retrieve his firearm. After thirty days, any firearms will be destroyed or forfeited to law enforcement for use or sale, according to the Kansas confiscation statute. ${ }^{197}$ The following statutory proposal would incorporate these provisions:

Upon entrance of a temporary or permanent protection from abuse order commanding the surrender of weapons, the court shall issue a search warrant allowing law enforcement to seize all firearms or ammunition named in the petition when there is probable cause to

196. N.H. ReV. StAT. ANN. § 173-B:4 (Supp. 2014).

197. KAN. STAT. ANN. § 22-2512 (2007). 
believe such weapons or ammunition are in the respondent's possession.

Upon service of such order, the respondent must turn over all firearms and ammunition to the law enforcement officer providing service. If the respondent does not surrender firearms voluntarily, the officer shall use the provided search warrant to enter the respondent's premises and confiscate all firearms and ammunition.

The firearm prohibition shall stay in effect until the protection from abuse order expires. Upon expiration, the respondent shall have thirty days to retrieve confiscated firearms or ammunition from law enforcement. After thirty days, confiscated material shall be disposed of in accordance with KSA $\S 22-2512$.

\section{B. Eliminating Judicial Bias}

\section{Mandating PFA Entrance}

Mandating the immediate confiscation of firearms upon entrance of a protection order could actually prove counterproductive if limits on judicial discretion are left unaddressed. If judges with strong personal beliefs about a person's right to bear arms are hesitant to enter orders without a state law that enters the arena of seizing firearms, ${ }^{198}$ surely the imposition of automatic confiscation will only intensify this hesitation. The solution is in further modification of the statute.

The key lies in clear and unambiguous language that instructs the court to enter a protective order when certain circumstances exist. ${ }^{199}$ The current Kansas statute authorizing the issuance of a temporary PFA explains that "upon a finding of good cause shown, the court ... may enter such temporary relief orders ... as it deems necessary to protect the plaintiff or minor children." 200 The statute authorizing any permanent PFA says "[t]he court may... grant any of the following orders," followed by a list of potential relief. ${ }^{201}$ These provisions are significant because by using the word "may," the statute creates the necessity for judicial decision, which will be subject to each judge's personal opinion and bias. If instead, the statutes utilized the word "shall" and mandated

198. See supra notes 139-42 and accompanying text.

199. See Benjamin Thomas Greer \& Jeffrey G. Purvis, Judges Going Rogue: Constitutional Implications When Mandatory Firearm Restrictions Are Removed from Domestic Violence Restraining Orders, 26 WIS. J.L. GENDER \& SOC'Y 275, 287 (2011) (describing the advantage of clear and unambiguous language in firearm restricting California protective order statutes).

200. KAN. STAT. ANN. §60-3106(b) (2005) (emphasis added).

201. Id. $\S 60-3107$ (a) (emphasis added). 
the entrance of an order under specific circumstances, judges would have less opportunity to interject personal decision-making and consequently subject the PFA entrance process to personal and potentially dangerous bias. $^{202}$

\section{Expanding the Definition of Abuse}

While the use of the word "shall" will be helpful in excluding judicial bias, the statute must also expand the definition of abuse to close loopholes that judges wary of denying gun rights or unaware of the danger of IPV may utilize. Currently, Kansas law allows a judge to enter a PFA to "bring about a cessation of abuse." 203 However, the definition of abuse is limited. ${ }^{204}$ The statute defines abuse as either physical abuse or sex with a minor under the age of sixteen when the minor is not the abuser's spouse. ${ }^{205}$ Not only does the statute ignore sexual assault, it also ignores any non-physical forms of abuse. ${ }^{206}$

The current definition leaves a great number of victims unprotected and could allow a wary judge to avoid entering a PFA when IPV is present in order to dodge any discussion of firearm restriction. Because IPV is unfathomably powerful in the way that it psychologically controls a victim, ${ }^{207}$ this is a dangerous situation. Many victims explain that the psychological abuse is often much worse than any physical violence. ${ }^{208}$ Tactics range from constant emotional or verbal manipulation to threats to kidnap common children. ${ }^{209}$ Escape from this abuse may very well depend on a protective order. Not only can the legal mandate provide physical separation from the manipulative abuser, the award of such an order also shifts the allocation of power within the relationship and forces the abuser into the public light, thus giving the victim the upper hand and a helpful boost to her psychological state. ${ }^{210}$

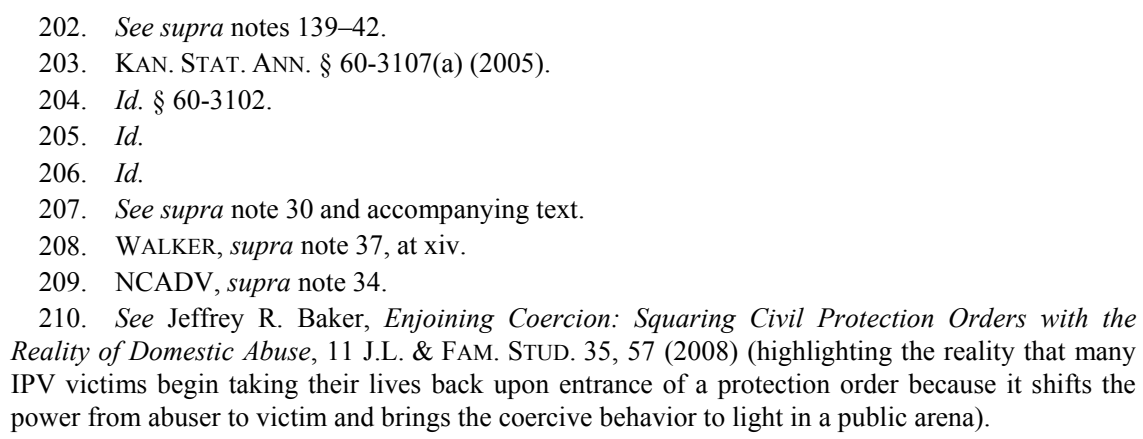

210. See Jeffrey R. Baker, Enjoining Coercion: Squaring Civil Protection Orders with the Reality of Domestic Abuse, 11 J.L. \& FAM. STUD. 35, 57 (2008) (highlighting the reality that many IPV victims begin taking their lives back upon entrance of a protection order because it shifts the power from abuser to victim and brings the coercive behavior to light in a public arena). 
As noted, the Kansas statute does not allow for a protection order in sexually, financially, or psychologically abusive situations. ${ }^{211}$ To remedy this danger, the statute could expand the definition of abuse to include any abuse used or intended to exert control over the victim. The Colorado legislative declaration concerning domestic violence provides a useful example of the type of language that should be included in a statutory definition of abuse. ${ }^{212}$ It recognizes the need for a protection order in the event of not only physical, but also sexual abuse. ${ }^{213}$ It then goes further, noting that "domestic abuse is not limited to physical threats of violence and harm but also includes mental and emotional abuse, financial control, document control, property control, and other types of control that make a victim more likely to return to an abuser due to fear of retaliation or inability to meet basic needs." 214 This language, coupled with mandatory enforcement when abuse exists, would bring the Kansas statute much closer to eliminating judicial bias and taking guns out of abusers' hands. The following provision would provide for such a result:

The court shall enter a protection from abuse order when the preponderance of the evidence shows that the respondent has perpetrated domestic abuse against the petitioner.

Abuse shall be defined as the occurrence of one or more of the following acts, whether actual, attempted, or threatened:

(a) physical abuse;

(b) sexual abuse;

(c) non physical forms of abuse, including but not limited to mental, emotional or financial control; or

(d) any other abusive act intended to coerce the petitioner into behavior from which he or she has the right to abstain.

3. Mandate Judicial Training

Another key component to protecting the lives of IPV victims falls on the judiciary. No matter how explicit and clear a statute may be, a

\footnotetext{
211. See Kan. Stat. AnN. §60-3102(b), (c) (2005) (identifying abuse only as physical violence or sexualviolence with a minor under sixteen who is not one's spouse).

212. Colo. ReV. StaT. § 13-14-100.2 (West 2014).

213. Id. § 13-14-100.2(3).

214. Id. § 13-14-100.2(2).
} 
judge must follow it or the statute will not have its intended effect. Unfortunately, in an area like IPV, the risk for judicial bias is great. ${ }^{215}$ It is a subject that is largely misunderstood, ${ }^{216}$ with a solution that threatens constitutional rights. ${ }^{217}$ The solution to ensuring that judges stay within the lines of the law lies in judicial training in the area of domestic violence. $^{218}$

With proper training, judges will obtain the tools to understand IPV and identify the abuse when it exists. ${ }^{219}$ Judges will know and appreciate that just because a woman does not leave an abusive relationship does not mean that the abuse is nonexistent or benign. ${ }^{20}$ Judges will understand that there are many ways to abuse someone, and no form of abuse is consistently less powerful than any other. ${ }^{221}$ This knowledge will provide the judges the ability to better identify abusive relationships and work to offer all possible legal protections.

\section{A Quicker Path to Appellate Review}

Because protection orders are "transitory in nature," and the process of appealing a judgment is generally a long one, PFA decisions are rarely subject to appellate review. ${ }^{222}$ If a petitioner were to appeal a PFA denial, the case would likely be moot by the time it reached the bench. ${ }^{223}$ The victim would either be dead, back with her abuser, or no longer subject to the abuse. Thus, erroneous trial level decisions are not likely to be reversed.

The result can be dangerous. When a victim is attempting escape, she is at the most treacherous point of IPV. ${ }^{224}$ It is during this period that she is most likely to be murdered by her abuser. ${ }^{225}$ If a protection order

215. Deutchman, supra note 91, at 227 (explaining that conscious and unconscious biases continue to exist in domestic violence cases).

216. See Baker, supra note 210, at 43-44 \& n.32 (explaining how the legal response to IPV focuses solely on the physical aspects of abuse, which are symptoms of IPV, not the disease itself).

217. See discussion infra Part III.D.

218. See Deutchman, supra note 91, at 227.

219. See id.

220. See WALKER, supra note 37, at 29-30 (dispelling the myth that women are free to leave an abusive relationship if it gets bad enough).

221. See NCADV, supra note 34 (listing a number of ways that abusers abuse).

222. Trolinger v. Trolinger, 42 P.3d 157, 159 (Kan. Ct. App. 2001).

223. See Skillet v. Sierra, 53 P.3d 1234, 1239 (Kan. Ct. App. 2002) (finding the issue whether the trial court had the authority to enter a protection order moot because the order had expired before the appeal).

224. See Deutchman, supra note 91, at 188.

225. Id. 
is wrongfully denied during this period, the victim is left without legal protection and faces an abuser who has seen no consequence for his actions. The victim's attempts to reach out for help, in the face of shame and fear, will have been rebuffed. Without any real ability to appeal the decision, she could find herself in a deadly situation with no legal options.

The potential danger of a wrongfully denied PFA creates a necessity for speedy access to appeals. This necessity remains important under the proposed reform. If mandated PFA implementation and judicial training does not prevent all judicial bias, the victims of IPV should have an avenue for review. This can be accomplished with a statutorily prescribed avenue to an expedited appeal.

Such avenues exist in other areas of the law, often in the juvenile arena. ${ }^{226}$ These examples can be imitated in the Kansas Protective Order statutes. The expedited appeal process outlined in Georgia Statute $\S 15$ 11-684 is a useful model. ${ }^{227}$ The provision provides a path to quick review when a juvenile court denies a youth's request for waiver of parental consent to an abortion. ${ }^{228}$ The youth must file a notice of appeal within five days and then the court must render a decision within five days after receipt of that notice of appeal. ${ }^{229}$ If the waiver is again denied, the youth may file a motion for reconsideration within five days and the court of appeals has another five days to reconsider. ${ }^{230}$ When a motion for reconsideration is denied, the youth can petition the Georgia Supreme Court for a writ of certiorari within twenty-four hours. ${ }^{231}$ The clerk has twenty-four hours to provide the petition to the Georgia Supreme Court, who shall then grant or deny the certiorari within two days. $^{232}$ The court has five days after granting certiorari to render a decision. ${ }^{233}$ At its maximum, this appeals process will take no longer than twenty-nine days with the youth afforded three chances at review. ${ }^{234}$

\footnotetext{
226. See Kan. Stat. ANN. § 38-2382 (Supp. 2014) (providing that an appeal from a juvenile adjudication must take place within thirty days); Gayle Nelson Vogel, Expediting Dependency Appeals, 26 CHILD. L. PRAC. 139, 141 (2007) (explaining the benefits of Iowa's expedited appellate procedure in juvenile law); GA. CODE ANN. § 15-11-684(e) (West Supp. 2014) (providing a path for quick review when a juvenile court denies a youth's request for waiver of parental consent to an abortion).

227. GA. CODE ANN. § 15-11-684(e) (West Supp. 2014).

228. Id.

229. GA. App. Ст. R. 45.

230. Id

231. GA. Sup. Cт. R. 62.

232. Id.

233. Id

234. See id.; GA. АрР. Cт. R. 45.
} 
If something similar to this Georgia appellate process is implemented in the Kansas PFA statute, IPV victims will retain a measure of safety during an incredibly dangerous period. This is especially true if the ex parte orders remain in place until the victim refrains from appeal or the Kansas Supreme Court renders a decision denying the order. Even in a case with no ex parte in place, if an abuser knows he is subject to more judicial scrutiny, the court appearance looming in his future may be enough to keep him from perpetrating any abuse in the interim.

\section{Withstanding Constitutional Challenge}

This proposal will likely face challenge under the Second Amendment to the U.S. Constitution. The amendment provides that "[a] well regulated Militia, being necessary to the security of a free State, the right of the people to keep and bear Arms, shall not be infringed. ${ }^{, 235}$ In 2008, the Supreme Court held that the Second Amendment confers an individual right to bear arms, thus limiting the government's ability to restrict firearm possession. ${ }^{236}$ Because the proposed reform requires that the government prohibit firearm possession while a PFA is in place, opponents may challenge its mandate on a theory that this restriction violates an individual's constitutional right to bear arms. While such a challenge is almost guaranteed to find traction in the judicial system, it should not prevail. The following analysis will reveal why the challenge should be denied, discussing the Second Amendment right, the requirements for constitutionally restricting this right, and the reasons that this proposal falls within those requirements.

\section{Defining the Right to Bear Arms}

Because the first ten amendments to the Constitution, or the Bill of Rights, historically applied only to the federal government, ${ }^{237}$ the Court returned to the Second Amendment discussion two years after its decision in Heller to determine the applicability of the provision to state actors. ${ }^{238}$ Until the late nineteenth century, state or private actors did not violate the first ten amendments by constricting any rights found therein. ${ }^{239}$ Over time, the Supreme Court greatly expanded the reach of

\footnotetext{
235. U.S. CONST. amend. II.

236. D.C. v. Heller, 554 U.S. 570, 592 (2008).

237. Id. at 625 .

238. See McDonald v. City of Chicago, 561 U.S. 742 (2010).

239. 2 Ronald D. Rotunda \& John E. Nowak, Treatise on Constitutional LaW-
} 
the Bill of Rights through a theory of incorporation. ${ }^{240}$ This theory provided that some rights were so fundamental they were protected as a liberty interest through the Fourteenth Amendment's Due Process Clause, a constitutional provision that does apply to state actors. ${ }^{241}$ The Supreme Court employed this incorporation theory when it returned to the Second Amendment discussion, holding that the right to bear arms would restrict state actors from interfering with that right just as it did the federal government. ${ }^{242}$

This right is not without limits, however. ${ }^{243}$ The majority in Heller announced that certain firearm restrictions were presumptively lawful, providing a list of examples and noting that the list was not exhaustive. ${ }^{244}$ The Court did not explain why the listed restrictions are presumptively lawful, or how lower courts should evaluate the constitutionality of other gun restrictions. ${ }^{245}$ The only guidance that the Court provided was to note that there must be a level of scrutiny that is higher than mere rational basis as the right is constitutionally enumerated. ${ }^{246}$ Thus, the only clear takeaway from Heller and McDonald is that there exists an individual right to a firearm, but that the federal or state government has the power to limit that right to some degree.

\section{Evaluating Gun Restrictions for Constitutional Validity}

This resolution leaves lower courts in the position of determining the constitutionality of any limit to a gun right when challenged in court. ${ }^{247}$ Historically, courts have often applied one of three standards of review in determining whether a law violates a constitutional right: ${ }^{248}$ rational

\footnotetext{
Substance AND PRocedure $§ 15.6$ (a) (2014) (explaining that the Bill of Rights did not apply to state actors until after the passage of the Fourteenth Amendment when the Court began identifying some of the rights as fundamental liberties protected by the Due Process Clause).

240. . McDonald, 561 U.S. at 744.

241. . Gerri L. Plain, Constitutional Law-Second Amendment—-the Second Amendment Right to Keep and Bear Arms is Applicable to the States Through Incorporation of the Due Process Clause of the Fourteenth Amendment, 41 CuMB. L. ReV. 161, 166 (2011).

242. McDonald, 561 U.S. at 791.

243. D.C. v. Heller, 554 U.S. 570, 626 (2008) (noting that the Second Amendment right is not unlimited).

244. Id. at $626-27 \&$ n. 26 .

245. Jeff Golimowski, Note, Pulling the Trigger: Evaluating Criminal Gun Laws in a PostHeller World, 49 AM. CRIM. L. REV. 1599, 1604 (2012).

246. Heller, 544 U.S. at 628 n.27, 686.

247. See Golimowski, supra note 245, at 1605.

248. Lindsay Goldberg, Note, District of Columbia v. Heller: Failing to Establish a Standard for the Future, 68 MD. L. REV. 889, 891-92 (2009).
} 
basis, intermediate scrutiny, or strict scrutiny. ${ }^{249}$ The rational basis test is the easiest for a gun restriction to overcome, and will find a law constitutional so long as it is rationally related to a legitimate government interest. ${ }^{250}$ Intermediate scrutiny has a higher threshold, deeming a law constitutional when it is substantially related to an important government interest. ${ }^{251}$ Finally, strict scrutiny will only allow a law to stand when it is narrowly tailored to further a compelling government interest. ${ }^{252}$

Until the Supreme Court articulates the appropriate standard for determining the constitutionality of gun restrictions, the opinions of the Kansas Supreme Court should ideally guide new reform of the Kansas PFA statute in an attempt to ensure constitutional validity. ${ }^{253}$ Unfortunately, like the Supreme Court, Kansas has not determined the appropriate standard of review. ${ }^{254}$ Because the Kansas judiciary has not identified what level of scrutiny will apply if a firearm restriction is challenged, there is no adequate guide for ensuring any reform is constitutional. However, this should pose little problem overall, as the proposed statute is capable of standing up to not only intermediate scrutiny, but strict scrutiny as well.

\section{Defining Intermediate Scrutiny}

Many courts outside Kansas have turned to intermediate scrutiny in evaluating the constitutionality of gun restrictions against the Second Amendment. ${ }^{255}$ Because this may make it more likely that a Kansas court will turn to this level of review if reform is challenged, this discussion turns first to that standard. A Tenth Circuit decision provides a useful example. ${ }^{256}$

\footnotetext{
249. Id.

250. Id. at 896 .

251. Id. at $897-98$.

252. Id. at 892 .

253. Any challenge to Kansas law is likely to begin in a Kansas state court. Legislation should thus attempt to follow the interpretations of the Kansas judiciary.

254. See State v. Curtiss, No. 102,604, 2010 WL 4977222, at *3 (Kan. Ct. App. Nov. 24, 2010) (noting that the appropriate level of scrutiny is unknown and the court will continue to refrain from deciding the appropriate level because the firearm restriction passes even the highest level of scrutiny).

255. United States v. Reese, 627 F.3d 792, 801 (10th Cir. 2010), cert. denied, 131 S. Ct. 2476 (2011) (observing that the Second, Third, and Seventh Circuits have applied intermediate scrutiny).

256. See generallyid.
} 
In 2010, the Tenth Circuit held 18 U.S.C. $§ \quad 922(\mathrm{~g})(8)^{257}$ constitutional as applied to a particular defendant after using a test of intermediate scrutiny. ${ }^{258}$ The Tenth Circuit did not address the constitutionality of the statute on its face because the defendant conceded its general validity after the district court found the amendment constitutional. ${ }^{259}$ Instead, the court assessed whether the act was unconstitutional in the specific circumstance of the named defendant. ${ }^{260}$

In the beginning steps, the court recognized that the government had an important objective in enacting the amendment, which was to keep firearms out of the hands of potential abusers. ${ }^{261}$ The court pointed to findings in a Seventh Circuit decision in support of that conclusion. ${ }^{262}$ The findings included various studies, one showing that domestic assaults with firearms were approximately twelve times more likely to end in homicide than assaults with knives or fists, another showing the high rate of recidivism among domestic violence offenders, and another that claimed eight percent of police fatalities were a result of officers' attempts to control a domestic disturbance. ${ }^{263}$ According to the Tenth Circuit, these numbers demonstrated that keeping guns out of the hands of abusers was an undeniably important government objective. ${ }^{264}$

The Tenth Circuit then assessed whether the means used to address this important objective were substantially related to the objective in the case at hand. ${ }^{265}$ The court decided that the defendant's prosecution under $\S 922(\mathrm{~g})(8)$ was substantially related to the government's interest in implementing the legislation because the underlying protective order to which the defendant was subject was tailored to certain kinds of abusers (those determined to have a propensity for violence) and complete with procedural protections. ${ }^{266}$

257. See supra notes $115-17$ and accompanying text.

258. See Reese, 627 F.3d at 803-04 (finding that the statute was constitutional as applied because it was consistent with an important government purpose).

259. Id. at 800 .

260. Id.

261. Id. at 802-03.

262. Id

263. Id.

264. Id. at 802 .

265. Id. at 803 .

266. Id. at $804 \&$ n. 4 . 
4. Applying Intermediate Scrutiny to the Proposed Reform

Like $\S 922(\mathrm{~g})(8)$ in the Tenth Circuit case, the statute proposed here for Kansas must be substantially related to an important government interest to pass a test of intermediate scrutiny. The first hurdle is an easy one. As in Reese ${ }^{267}$ there is little question that the statute serves an important government interest. The state naturally has an interest in protecting citizens from murder or abuse. Statistics illustrate the high frequency of death threats ${ }^{268}$ and the strong likelihood of homicide when a domestic abuser possesses a firearm. ${ }^{269}$ Because the proposed statute aims to prevent these realities, the statute easily serves an important government interest.

The second obstacle in the intermediate scrutiny test is identifying the proposed reform as substantially related to the objective. ${ }^{270}$ Because the reform suggests two different provisions that could separate a person from a firearm, the analysis must proceed in two separate discussions. The first proposal mandates firearm removal in the case of physical violence. Showing that this is substantially related to an interest in preventing IPV homicide is not a difficult barrier to overcome. Studies show that firearms and IPV are deadly. One study reveals that seventyfour percent of IPV homicide victims and eighty-eight percent of attempted IPV homicide victims had been seen in the emergency department in the year before their murder or attempted murder. ${ }^{271}$ This result supports the conclusion that abusers who murder their intimates present warning signs of physical violence.

Another study revealed that around two thirds of women who lived in IPV situations where there was a gun in the home reported that their partners used the gun against them, ${ }^{272}$ giving weight to the assumption that more often than not, firearms will be used to abuse the victim when an abuser has access to the weapon. A 2003 study revealed that a woman's risk of homicide increases by 500 percent when a gun is

267. Id. at 802 (explaining that not even the challenger to the legislation heavily contests the assertion that keeping guns out of the hands of abusers is an important government interest).

268. EVERYTOWN, supra note 17, at 4 (noting one study where two-thirds of women living in a home with a gun reported that their abuser had used the gun against them, usually to threaten death).

269. See supra notes $85-90$ and accompanying text.

270. See supra note 252 and accompanying text.

271. Jacquelyn C. CAmpbell et al., Intimate Partner Violence Risk Assessment VALIDATION STUDY, U.S. DEP'T OF JUST., 3 (2005), https://www.ncjrs.gov/pdffiles1/nij/grants/209 731.pdf.

272. Firearms Policy Summary, supra note 85. 
present in an IPV situation. ${ }^{273}$ Because IPV murderers have shown to present warning signs of physical violence, and most abusers who own weapons use them against their victims, taking away the guns when an abuser shows signs of physical abuse is clearly related to the state's interest in preventing IPV and IPV homicide.

The other question in this piece of the analysis is whether allowing a judge to remove weapons when non-physical forms of IPV exist is also substantially related to the government interest. Upon first glance, the link between financial, emotional, or psychological abuse and gun violence may seem too attenuated to support the idea that removing weapons from a psychological abuser will prevent the murder or continued abuse of a partner. However, as this discussion reveals, the attenuation is not so great. The literature on domestic violence repeatedly declares two things: the violence in IPV relationships generally begins benignly and escalates over time, ${ }^{274}$ and the moment of escape is often the most dangerous point in a victim's life. ${ }^{275}$

The psychology behind convincing a woman to love a person who is throwing her head against a wall is slow, intricate, and systematic. ${ }^{276}$ Thus, victims often do not even realize that they are in a dire situation until physical violence is already present. ${ }^{277}$ However, if a victim tries to extricate herself early in the relationship, before any physical violence has started, she could be in just as much danger as the woman who has been subject to physical abuse for years. ${ }^{278}$ Thus, allowing a judge to remove a firearm when she finds non-physical abuse present in a relationship is still substantially related to the state's interest in avoiding IPV and IPV homicide. An evaluation of this provision should take special notice that it does not mandate the removal of firearms upon a finding of non-physical abuse. While mandated entrance would almost surely pass a rational basis test, ${ }^{279}$ this more generous provision will

273. Id

274. See Abuse Defined, The NAT'L DOMEStic Violence Hotline, http://www.thehot line.org/is-this-abuse/abuse-defined/ (last visited May 21, 2015).

275. Supra note 95 and accompanying text.

276. See WALKER, supra note 37, at 55-70 (describing the cycle of violence and a victim's subjection to the manipulative stages of abuse).

277. See id. at 71-72 (relaying questions from victims who were suffering psychological abuse but were unsure if they were experiencing domestic violence because there was no physical abuse).

278. See NCADV, supra note 34.

279. Rational basis only necessitates that government action is rationally related to a legitimate government interest. Goldberg, supra note 248, at 896. With such a low threshold, government action rarely fails a challenge. Stephen Kiehl, In Search of a Standard: Gun Regulations After Heller and McDonald, 70 MD. L. REV. 1131, 1136 n.58 (2011). A provision that seeks to remove firearms from known abusers would have little trouble withstanding such a test. 
allow the test to pass higher levels of scrutiny because it does not automatically subject all abusers to Second Amendment restrictions. ${ }^{280}$

Finally, the limited time frame of the protective orders will greatly assist the proposed reform in withstanding the intermediate scrutiny of a court. Any confiscation of firearms, either statutorily or judicially mandated, will not be indefinite. This proposal does not attempt to extend the length of the current PFA, which generally lasts no longer than one year unless it is extended for another year upon motion of the victim. ${ }^{281}$ Thus, the means used to meet the government's interest in protecting IPV victims are targeted directly at those likely to perpetrate IPV and are very limited in duration. Consequently, these means are substantially related to the government's objective.

\section{Defining Strict Scrutiny}

While intermediate scrutiny is the most invoked and thus most likely applicable standard of review, some courts turn to strict scrutiny when fleshing out the constitutional validity of a gun restriction. ${ }^{282}$ These courts will only uphold a restriction if they find it furthers a compelling government interest and the restriction is narrowly tailored to achieve that interest. ${ }^{283}$ Generally reserved for the protection of fundamental rights and suspect classes, this is the highest standard of review and thus more difficult to overcome. ${ }^{284}$ While often described as "strict in theory and fatal in fact," strict scrutiny actually upholds challenged regulations in thirty percent of applications. ${ }^{285}$ Thus, while the analysis presents a more demanding challenge than lower levels of scrutiny, it appears that the test is not "fatal in fact," but rather "survivable in fact." 286

The first step in withstanding a strict scrutiny challenge is to identify a compelling government interest that the challenged regulation

280. United States v. Reese, 627 F.3d 792, 804 n.4 (10th Cir. 2010) (explaining that the gun restriction could pass even strict scrutiny because it only subjected certain abusers to the firearm prohibition).

281. Kan. StaT. AnN. § 60-3107(e) (Supp. 2014).

282. Elizabeth Silvestri, Comment, Constitutional Law - Fourth Circuit Applies Intermediate Scrutiny to Second Amendment Challenge-Woollard v. Gallagher, 712 F.3d 865 (4th Cir. 2013), cert. denied, 134 S. Ct. 442 (2013), 47 SuFFoLK U. L. REV. 215, 219 (2014).

283. Goldberg, supra note 248 , at 892.

284. See id. at 892-98 (identifying when strict scrutiny applies and explaining that this level of review emerged when the court needed to apply "the most rigid scrutiny").

285. Adam Winkler, Fatal in Theory and Strict in Fact: An Empirical Analysis of Strict Scrutiny in the Federal Courts, 59 VAND. L. REV. 793, 794-96 (2006).

286. Id. at 796 
serves. $^{287}$ The Supreme Court has not articulated specific criteria for a compelling interest, and indeed, the definitions and types of such interests vary throughout case law and legal writing, and likely depend on the subject matter at stake. ${ }^{288}$ The language used seems to generally describe compelling interests as those that are "only the most pressing circumstances," ${ }^{289}$ or a "vital interest." 290 Examples of interests the Supreme Court has found compelling include "remedying the effects of past intentional discrimination," 291 securing diversity in higher education, ${ }^{292}$ "protecting [the] potential life" of an unborn fetus, ${ }^{293}$ "removing the victims of child abuse from their parents," 294 and maintaining highway safety. ${ }^{295}$

In evaluating gun restrictions, a number of lower courts have found compelling interests behind regulations aimed at keeping the public safe. When the Third Circuit affirmed the conviction of a defendant for possessing a handgun with an obliterated serial number, the court held that the serial number tracking system helped law enforcement collect valuable information from recovered weapons and was thus a compelling interest. ${ }^{296}$ The First Circuit upheld a Massachusetts law that required applications for firearms licenses to contain accurate information, subject to revocation of a license or criminal conviction for knowingly false reporting. ${ }^{297}$ The court held that the law would pass even the highest level of scrutiny, thus identifying the truthful information requirement as a compelling interest. ${ }^{298}$ In an application of intermediate scrutiny, the Seventh Circuit wasted no time in deeming the reduction of domestic gun violence an important government interest after noting that the Supreme Court had already found such an interest compelling. ${ }^{299}$ Kansas

287. Richard H. Fallon, Jr., Strict Judicial Scrutiny, 54 UCLA L. REV. 1267, 1321 (2007).

288. See id. at 1321-22 (describing the variance in compelling interests named by the Supreme Court and possible reasons behind each choice).

289. Winkler, supra note 285, at 800.

290. Meghan Newcomer, Note, Can Condoms be Compelling? Examining the State Interest in Confiscating Condoms from Suspected Sex Workers, 82 FordHAM L. Rev. 1053, 1060 (2013).

291. Parents Involved in Cmty. Schs. v. Seattle Sch. Dist. No. 1, 551 U.S. 701, 720 (2007) (describing the compelling interest in Freeman v. Pitts, 503 U.S. 467, 494 (1992)).

292. Grutter v. Bollinger, 539 U.S. 306, 343 (2003).

293. Roe v. Wade, 410 U.S. 113, 154 (1973).

294. Stephen E. Gottlieb, Compelling Governmental Interests: An Essential but Unanalyzed Term in Constitutional Adjudication, 68 B.U. L. REV. 917, 950 (1988).

295. Id. at 951.

296. United States v. Marzzarella, 614 F.3d 85, 99 (3d Cir. 2010).

297. Hightower v. City of Boston, 693 F.3d 61, 64-65 (1st Cir. 2012).

298. Id. at 74 .

299. United States v. Skoien, 587 F.3d 803, 814 (7th Cir. 2009), vacated on other grounds, No. 08-3770, 2010 WL 1267262 (7th Cir. Feb. 22, 2010). The Supreme Court decision referenced by 
has also found compelling interests for certain gun restrictions. ${ }^{300}$ In 2010, the Kansas Court of Appeals upheld a statute prohibiting felons from possessing firearms when it named the state's goal of protecting the citizenry a compelling interest. ${ }^{301}$

The second prong of the strict scrutiny test requires that the means used to further the compelling interest be narrowly tailored. ${ }^{302}$ There is slightly more guidance for this piece of the analysis than exists for defining a compelling interest. ${ }^{303}$ Some literature suggests that an investigation into whether a regulation is narrowly tailored generally proceeds in a series of parts. ${ }^{304}$ According to this explanation, a court will first ensure that the restriction will actually further the asserted compelling interest. ${ }^{305}$ The court then inquires whether the regulation is overinclusive, meaning the regulation "restricts a significant amount of [behavior] that doesn't implicate the government interest." ${ }^{306}$ Next, the court examines whether the regulation is underinclusive, or "fails to restrict a significant amount of [behavior] that harms the government interest." ${ }^{\text {"307 }}$ Finally, the court ensures that the regulation presents the least restrictive means possible of furthering the government interest. ${ }^{308}$ Commentators note, however, that the Supreme Court has not been consistent in this analysis, and has upheld laws that seemingly fail at least one part of the aforementioned assessment. ${ }^{309}$

Examples of narrowly tailored interests may be helpful in painting a picture of the second prong of strict scrutiny. In 1988, the Supreme Court upheld a municipal ordinance prohibiting picketing in front of residences or dwellings, declaring the regulation narrowly tailored to the city's purpose of protecting residential privacy because it was "narrowly

\footnotetext{
the court held that the government's interest in preventing crime was compelling. Id. (citing United States v. Salerno, 481 U.S. 739 (1987)).

300. State v. Curtiss, No. 102,604, 2010 WL 4977222, at *3 (Kan. Ct. App. Nov. 24, 2010).

301. Id.

302. Matthew D. Bunker et al., Strict in Theory, but Feeble in Fact? First Amendment Strict Scrutiny and the Protection of Speech, 16 COMM. L. \& POL'Y 349, 350 (2011).

303. Eugene Volokh, Freedom of Speech, Permissible Tailoring and Transcending Strict Scrutiny, 144 U. PA. L. REV. 2417, 2421-24 (1996) (describing a four-part analysis for determining whether a regulation is narrowly tailored).

304. Id.

305. Id. at 2422.

306. Id.

307. Id. at 2423 .

308. Id. at 2422 .

309. Fallon, supra note 287, at 1328-29.
} 
directed at the household, not the public," and "[left] open ample alternative channels of communication." ${ }^{\text {"10 }}$

In contrast, in 1982 the Supreme Court refused to sanction a state statute prohibiting the general public from criminal trials when it held it was not narrowly tailored to either of the state's purported goals. ${ }^{311}$ The state argued that the law helped to ensure the well-being of minors in the courtroom and encourage minor victims of sex crimes to come forward and provide testimony. ${ }^{312}$ As to the first goal, the Court reasoned that the interest could be achieved by closing the courtroom on a case-by-case basis, rather than excluding the general public at large in every trial. ${ }^{313}$ Turning to the second interest, the Court pointed out that the state had provided no support for the connection between the regulation and an increased number of sex victims coming forward to cooperate, thus failing to show that the regulation would further the interest. ${ }^{314}$ Similarly, in 2007, the Supreme Court held that a student assignment plan that relied on race classification was not narrowly tailored when the school failed to show that the plan was necessary to achieve its goal of educational and social benefits. ${ }^{315}$

For examples of narrowly tailored gun restrictions, one must turn to lower court decisions. In United States v. Marzzarella, the Third Circuit found the statute criminalizing the possession of a gun without a serial number narrowly tailored because it did not limit the possession of an otherwise lawful firearm and thus did not burden more possession than necessary. ${ }^{316}$ The Tenth Circuit, while applying intermediate scrutiny in an evaluation of $\S 922(\mathrm{~g})(8)$, reported that the restriction would withstand strict scrutiny as a narrowly tailored regulation, because it only mandated firearm restriction for persons subject to a certain kind of domestic protection order. ${ }^{317}$ Closer to home, the Kansas Court of Appeals held that the statute prohibiting felons from possessing firearms passed the second prong of the strict scrutiny test after noting that it did not "prevent all criminals from possessing firearms for an indeterminate period of time. Rather, the statute [was] tailored to prohibit possession of firearms for varying periods of time depending upon the nature of the

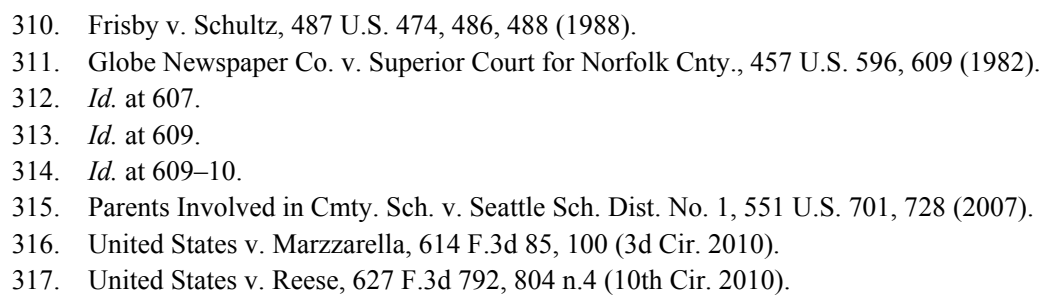


underlying crime."318 The court placed additional significance on the fact that "even the most violent felons are not subject to a lifetime ban on firearm possession." 319

\section{Strict Scrutiny and the Proposed Reform}

The preceding discussion reveals the hurdles of the strict scrutiny test but also the high potential for the proposed firearm restriction to surpass its barriers. The first prong should pose little trouble. The cited examples illustrate the breadth of compelling interests that the judiciary has recognized. ${ }^{320}$ Each noted example centers around protecting citizens from some kind of evil or danger. Crime prevention, highway safety, privacy, and abuse elimination all top the list of recognized priorities. $^{321}$ The prevention of intimate partner homicide or abuse is consistent with this list. In fact, Kansas has specifically recognized the protection of the citizenry as a compelling interest when imposing gun restrictions. ${ }^{322}$ Because the proposed restriction purports to do just this, a reviewing court would likely find the purpose behind the proposed restriction a compelling interest.

The narrow tailoring requirement would face greater challenge. While the Supreme Court does not always engage the four part analysis mentioned previously, ${ }^{323}$ for the sake of assessing whether the proposed reform could withstand even the strictest of scrutiny, this Comment assumes that each piece would be utilized by a reviewing court. First, the reform must actually address the compelling interest it seeks to achieve. $^{324}$ Research shows that when abusers possess firearms, the chance of homicide soars. ${ }^{325}$ Admittedly, this statistic alone does not prove that removing firearms through protection orders will lower the statistic. However, when buttressed by a study showing that intimate partner homicide decreases by an average of eight percent when protection orders prohibit firearm possession, ${ }^{326}$ the first statistic becomes more important. The proposed reform has proven responsive in lowering the soaring chance of homicide when an abuser has a

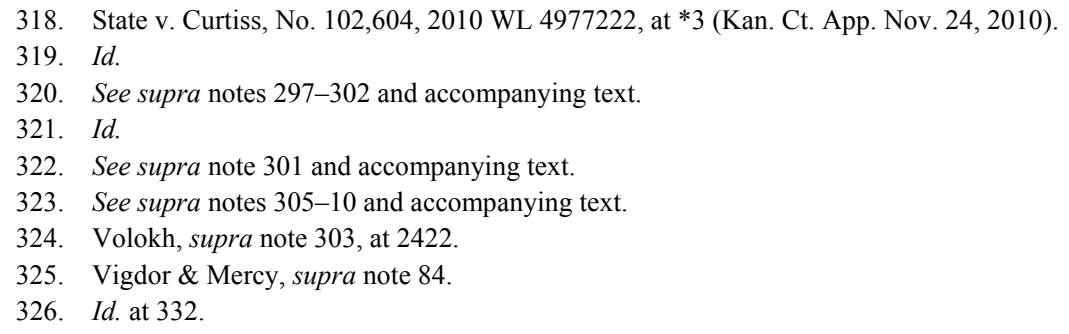


weapon. $^{327}$ Consequently, prohibiting known abusers from possessing weapons is narrowly tailored insofar as it will address the government's compelling interest.

Narrow tailoring also requires that the restriction is neither underinclusive nor overinclusive. ${ }^{328}$ To avoid being underinclusive, the reform cannot ignore substantial parts of the problem that the restriction seeks to address. ${ }^{329}$ Because this statute focuses specifically on those perpetrating abuse, and not just those who have been convicted of a domestic violence crime, it hones in on all of the parties with potential to use a firearm against a victim. One study revealed that only twelve percent of reported IPV offenses result in a conviction. ${ }^{330}$ Were the statute to ignore all abusers who were not included in that twelve percent, the reform would teeter dangerously close to underinclusive. The inclusivity of all abusers creates the opposite effect.

The reform evades an overinclusive status so long as it does not substantially regulate behavior that does not implicate the compelling interest. ${ }^{331}$ Opposition to the proposed reform may correctly point out that not all who are subject to a protective order will murder or abuse their partners. This is undoubtedly true. However, the proposed restriction will not be imposed without reason or review. An emergency protection order, while imposed ex parte, is still imposed by a judge, after a review of alleged fact and a determination that the petitioner is being abused. A full protection order is only awarded after a hearing in which the alleged abuser will have the opportunity to be heard and disprove the allegations.

Further, both forms of protection order are limited in duration. The emergency ex parte expires after three weeks and the permanent order remains in place no longer than one year. These factors limit the reach of the restriction, ensuring it is not overinclusive. Like the prohibition of firearms for felons that was evaluated by the Kansas Court of Appeals, ${ }^{332}$ the focus on perpetrators of violence and the limited duration of this restriction is a strong indicator of narrow tailoring.

\footnotetext{
327. Id.

328. Volokh, supra note 303, at 2422-23.

329. Id. at 2423.

330. Joel H. Garner \& Christopher D. Maxwell, Prosecution and Conviction Rates for Intimate Partner Violence, 34 CRIM. Just. REV. 44, 51 (2009).

331. Volokh, supra note 303, at 2422.

332. See supra notes 301, 319 and accompanying text.
} 
Finally, the reform must be the least restrictive means of achieving the government interest. ${ }^{333}$ This is the most challenging obstacle for the proposed reform. The statute's broad inclusion of all who are subject to a protection order, potentially (although temporarily) before they have a chance to be heard, appears overly restrictive. A look to alternative restrictions may help to evaluate if this is in fact the least restrictive method. The first alternative is perhaps the most obvious: the elimination of mandated firearm removal upon entrance of a temporary protection order entered ex parte. This would undoubtedly result in a less restrictive statute. However, excluding this provision would reduce the effectiveness of the statute and create potential for an underinclusive statute. Studies reveal that the most dangerous time for a victim is when she tries to leave. ${ }^{334}$ Abolishing the mandated firearm removal upon entrance of an emergency order could render a PFA totally ineffectiveif the abuser has a deadly weapon, he may use it when his victim tries to escape, or the victim may not even attempt to leave. Consequently, while this would be less restrictive, it would not be as effective in achieving the government interest. Another less restrictive reform would be removing firearms only when there is a domestic violence conviction. However, as discussed above, there are a very small number of convictions compared to reported offenses. ${ }^{335}$ Thus, such a limited restriction would disregard the majority of abuse perpetrators, resulting in a statute that barely attends to the government interest.

The failure to identify a less restrictive means may still fall short of demonstrating that this reform is as narrow as required by strict scrutiny. To support the assertion that this restriction is indeed narrowly tailored, one can turn to the fact that the reform does not mandate firearm removal for all abusers. The proposed statute only commands that guns be turned over when there is actual or threatened physical or sexual abuse. With all other forms of abuse, the option to confiscate firearms is left to the judge. This detail may prove to be the pressure valve that satisfies the concerns of those dedicated to strictly upholding Second Amendment rights. The statute will not take firearms from all abusers, only those who prove to be the most violent and the most dangerous to the physical well being of their victims.

333. Volokh, supra note 303, at 2422.

334. Gold, supra note 35, at 940.

335. Garner \& Maxwell, supra note 330. 
Thus, while intermediate scrutiny appears to be the emerging choice for evaluating gun restrictions, ${ }^{336}$ in the event that courts apply a higher level of scrutiny, the proposed reform should still withstand review. Because protecting the people from abuse and homicide is an imperative goal, and the reform is both limited in duration and only applicable to the most violent abusers, the proposed reform has a high chance of enduring a strict scrutiny analysis.

\section{E. The Importance of Reform in Today's Political Climate}

This reform is even more necessary today than in the past. State laws that purport to nullify federal firearms regulations are sweeping the country. ${ }^{337}$ While the federal government has dismissed Kansas's nullification law as unconstitutional and invalid, the legislation remains on the books. ${ }^{338}$ Kansas is quite possibly of the mindset that $\S 922(\mathrm{~g})(8)$ will not apply to abusers so long as their weapons were created inside and kept within state lines. ${ }^{339}$ This is a dangerous mindset.

Even if the nullification manifests no legal consequence and the federal government continues to prosecute under $\S 922(\mathrm{~g})(8),{ }^{340}$ its influence on judges reviewing PFA cases could be dramatic. Judges in Kansas may be informing abusers that under federal law they cannot possess a firearm while subject to a PFA, thus potentially reducing the number of abusers with deadly weapons in their possession. If Kansas insists that this is not necessarily the law as it applies to Kansans with Kansas guns, those judges may refrain from telling abusers they must hand over their weapons. This not only strips the victim of any protection the judge's reminder to the abuser may provide, but potentially leaves the respondent unaware that he is committing a federal offense by keeping his firearm. Because it is lethally dangerous to allow abusers to keep weapons that they are likely to employ as a tool of abuse, and because the nullification law eliminates protections the victims currently have under federal law, Kansas should enact the proposed reform and mandate removal of these weapons.

\footnotetext{
336. United States v. Reese, 627 F.3d 792, 801 (10th Cir. 2010) (noting that the Third and Seventh Circuits have applied intermediate scrutiny).

337. See supra Part II.E.

338. See supra notes $158-73$ and accompanying text.

339. See supra Part II.E.

340. See supra notes $158-73$ and accompanying text.
} 


\section{CONCLUSION}

This reform is more than necessary in the fight to save the lives of IPV victims and end abuse. Women are murdered at the hands of intimate partners every year, most often when their partners are pointing a firearm. ${ }^{341}$ There is little reason to allow abusers to hold on to firearms when statistics show that doing so is fundamental in increasing IPV homicide.

The new statute should not only mandate the removal of these firearms when there is physical abuse present or threatened, but it should allow a judge to remove firearms upon the presence of non-physical forms of abuse. Because the most dangerous time in an IPV relationship is when a woman tries to escape, ${ }^{342}$ a judge should have the power to remove a firearm when doing so will be important in saving the victim's life or helping her escape. In addition to this reform, Kansas should mandate substantial IPV training for any judge who may hear PFA cases. This will help prevent judicial bias because of a belief in gun rights. ${ }^{343}$

Finally, the statute should provide an avenue for expedited appeal. Because judges can make mistakes, and in this setting a mistake could mean the victim's life, there must be a process for prompt appeal. These reforms will put Kansas on the path to ending IPV and saving its victims from homicide.

341. See supra notes $87-90$ and accompanying text.

342. Gold, supra note 35, at 940.

343. See supra notes $135-42$ and accompanying text. 


\section{APPENDIX: PROPOSED STATUTE}

The court shall enter a protection from abuse order when the preponderance of the evidence shows that the respondent has perpetrated domestic abuse against the petitioner.

Abuse shall be defined as the occurrence of one or more of the following acts, whether actual, attempted, or threatened:

(a) physical abuse;

(b) sexual abuse;

(c) non physical forms of abuse, including but not limited to mental, emotional or financial control; or

(d) any other abusive act intended to coerce the petitioner into behavior from which he or she has the right to abstain.

This order shall mandate the surrender of all firearms and ammunition and prohibit the purchase of firearms and ammunition when there has been an incident of:

(a) physical or sexual abuse;

(b) attempted physical or sexual abuse; or

(c) threatened physical or sexual abuse.

The court may order the surrender of all firearms and ammunition and prohibit the purchase of firearms and ammunition when there is a presence of non-physical domestic abuse.

Upon entrance of a temporary or permanent protection from abuse order commanding the surrender of weapons, the court shall issue a search warrant allowing law enforcement to seize all firearms or ammunition named in the petition when there is probable cause to believe such weapons or ammunition are in the respondent's possession.

Upon service of such order, the respondent must turn over all firearms and ammunition to the law enforcement officer providing service. If the respondent does not surrender firearms voluntarily, the officer shall use the provided search warrant to enter the respondent's premises and confiscate all firearms and ammunition.

The firearm prohibition shall stay in effect until the protection from abuse order expires. Upon expiration, the respondent shall have thirty days to retrieve confiscated firearms or ammunition from law 
enforcement. After thirty days, confiscated material shall be disposed of in accordance with KSA § 21-6307. 